\title{
PERBEDAAN KEBIJAKAN PERTAHANAN \\ PARTAI BURUH AUSTRALIA \\ ERA PEMERINTAHAN HAWKE-KEATING DAN KEVIN RUDD
}

\author{
Febe Maryona Tahitu \\ Dosen Administrasi Publik, Fakultas Ilmu Sosial, \\ Universitas Victory Sorong
}

\begin{abstract}
Abstrak
Pasca PD II Australia mencari sandaran negara besar pengganti Inggris dalam politik pertahanannya. Di dalam Defence White Paper 2009 era Kevin Rudd, Australia menyatakan bahwa kebijakan pertahanan yang baru salah satunya adalah Self-Reliance yang intinya adalah kebijakan yang mengarah pada pertahanan kedaulatan dengan berdasarkan prinsip kemandirian. Defence White Paper 2009 ini sangat berbeda dari kebijakan pertahanan Partai Buruh sebelumnya era Pemerintahan Hawke-Keating. Dalam hal ini, arah kebijakan dalam Defence White Paper 1987 dan Defending Australia 1994 adalah memprioritaskan aliansi dengan Amerika Serikat. Sejak Perang Dunia II, setelah "terlepas" dari Inggris. Pandangan strategis dan perencanaan pertahanan Australia dibentuk atas perubahan lingkungan internasional serta distribusi kekuatan global, khususnya keunggulan strategis Amerika Serikat. Amerika Serikat telah memainkan peran stabilitator di seluruh dunia dan khususnya di kawasan Asia-Pasifik. Hubungan pertahanan Australia dan Amerika Serikat yang sudah terjalin lama dan berlangsung harmonis, hal ini memberikan dampak bagi kebijakan pertahanan Australia. Artinya bahwa Amerika Serikat selalu menjadi dasar pilihan dalam setiap kebijakan pertahanan Australia. "Ketergantungan" dengan Negara besar membawa Australia pada citra sebagai "pihak asing” di kawasan Asia.
\end{abstract}

Kata kunci : Kebijakan, Australia

\section{PENDAHULUAN}

Pasca PD II Australia mencari sandaran negara besar pengganti Inggris dalam politik pertahanannya. Revisi demi revisi Defence White Paper merupakan varian dari Forward Defence yang menitikberatkan pada prinsip kemandirian dengan fokus regionalisme. Dalam Bab 6 ayat 19 Defence White Paper 2009 era Kevin Rudd, Australia menyatakan bahwa kebijakan pertahanan yang baru salah satunya adalah Self-Reliance yang intinya adalah kebijakan yang mengarah pada 
pertahanan kedaulatan dengan berdasarkan prinsip kemandirian. ${ }^{10}$ Dengan kata lain, Defence White Paper 2009 merupakan bentuk pernyataan resmi Australia untuk membangun sistem pertahanan yang independen setelah sekian lama mengadakan aliansi untuk menjamin keamanannya. Penulis melihat Defence White Paper 2009 ini sangat berbeda dari kebijakan pertahanan Partai Buruh sebelumnya era Pemerintahan Hawke-Keating.

Dalam hal ini, arah kebijakan dalam Defence White Paper 1987 dan Defending Australia 1994 adalah memprioritaskan aliansi dengan Amerika Serikat. Konsep yang dianut yaitu Forward Defence yang artinya pertahanan di garis depan Australia yang didalamnya masih terdapat aliansi. Penulis menemukan ada perbedaan dalam kedua kebijakan tersebut. Menarik bagi penulis untuk menelusuri mengapa Defence White Paper 1987, 1994 dan Defence White Paper 2009 berbeda, padahal notabene Hawke-Keating dan Kevin Rudd berasal dari Partai yang sama.

Australia adalah sebuah negara yang terdapat di belahan bumi bagian selatan yang juga merupakan benua terkecil di dunia. Di sebelah barat Australia berbatasan dengan Indonesia dan Papua New Guinea, sedangkan di sebelah timur berbatasan dengan Solomon, Fiji dan Selandia Baru. Meskipun Australia terletak didekat Asia, namun negara ini sering disebut sebagai bagian dari Dunia Barat. Jika di lihat dari sejarah Australia maka negara ini memiliki persamaan hidup dan budaya yang sama dengan bangsa barat terutama Kerajaan Inggris karena sebelum terbentuk federasi Australia, Australia merupakan koloni Inggris.

Australia menjadi negara saat federasi dari koloni-koloni yang terpisah terbentuk pada tanggal 1 Januari 1901. Dalam bidang politik, terdapat tiga partai besar yang cukup berkuasa yaitu Partai Buruh, Partai Liberal, Partai Nasional. Partai Buruh Australia (Australian Labor Party-ALP) adalah sebuah partai politik sayap kiri-tengahAustralia. Partai Buruh Australia (Australian Labor Party-ALP) didirikan pada tahun 1891 dan merupakan partai politik tertua yang aktif dalam pemerintahan federal di negara tersebut. Partai Buruh Australia (ALP) adalah

10 "Australia's Defence Policy", dalam http://www.defence.gov.au/whitepaper/docs/defence_white_paper_2009.pdf, diakses pada 30 Maret 2012. 
peserta pada pemilu 1901 yang diadakan sesaat setelah Federasi Australia terbentuk.

Politik luar negeri Australia sejak federasi 1901 sampai 1933 merupakan bagian dari kebijakan luar negeri Pemerintah Kerajaan Inggris. Pemerintah Inggris mewakili dan memfasilitasi semua kepentingan Australia dalam hubungan luar negerinya. Dalam hal pertahanan dan Keamanan, Australia dijamin oleh Inggris. Perdagangan luar negerinya yang utama berlangsung dengan Inggris. Pasca Perang Dunia II, Angkatan Bersenjata Inggris yang seharusnya mampu memposisikan diri sebagai pelindung bagi pertahanan Australia ternyata tidak mampu menahan serangan dan invasi Jepang di wilayah Pasifik. Invasi Jepang di kepulauan Pasifik membuat banyak warga Australia dan pemerintah Australia merasa tidak aman akan keadaan tersebut.

Ini kemudian terbukti dengan berhasilnya tentara Jepang memasuki wilayah Australia. Rasa tidak aman dengan sendirinya memicu Australia untuk mencari kekuatan baru yang bisa melindungi dan membuat mereka merasa aman yang mana selama ini tidak mampu dilaksanakan oleh Inggris. Oleh karena itu Australia mencari perlindungan yang baru berupa kekuatan atau kekuasaan dari Amerika Serikat. Setelah "terlepas" dari Inggris, pandangan strategis dan perencanaan pertahanan Australia dibentuk atas perubahan lingkungan internasional serta distribusi kekuatan global, khususnya keunggulan strategis Amerika Serikat.

Amerika Serikat telah memainkan peran stabilitator di seluruh dunia dan khususnya di kawasan Asia-Pasifik. Hubungan pertahanan Australia dan Amerika Serikat yang sudah terjalin lama dan berlangsung harmonis, hal ini memberikan dampak bagi kebijakan pertahanan Australia. Artinya bahwa Amerika Serikat selalu menjadi dasar pilihan dalam setiap kebijakan pertahanan Australia. “Ketergantungan” dengan Negara besar membawa Australia pada citra sebagai "pihak asing" di kawasan Asia. Dalam hal perumusan kebijakan pertahanan, terdapat berbagai pilihan-pilihan utama yang selalu menjadi fokus perhatian dari setiap pemimpin Australia. Pertama, apakah Australia harus terus bergantung pada perlindungan negara-negara besar seperti Amerika Serikat dan Inggris, yang 
dinilai dapat memberikan jaminan keamanan bagi Australia. Kedua yaitu apakah Australia perlu membangun sistem pertahanan yang mandiri sehingga diharapkan dapat lebih aktif dalam upaya serta inisiatif di forum internasional. Ketiga yaitu apakah Australia harus bertarung diluar negeri yang berkaitan dengan konsep Forward Defence atau Australia harus berperang didalam negeri yang sesuai dengan konsep Continental Defence.

Pada tanggal 18 Oktober 1980, Bob Hawke terpilih ke Parlemen Federal sebagai wakil dari Partai Buruh Australia untuk Wills, Victoria konstituen. Ia memenangkan kursi ini dalam empat pemilu berturut-turut 1983, 1984, 1987 dan 1990. Pada bulan Maret 1983 pimpinan partai Buruh Bob Hawke menggantikan perdana menteri Fraser dari koalisi Partai non Buruh. Bob Hawke merumuskan kebijakan pertahanan dalam sebuah buku putih pertahanan Australia yang dikenal dengan Defence White Paper 1987.

Pada masa itu, Bob Hawke melalui Beazley meminta Paul Dibb untuk meninjau isi, prioritas dan dasar pemikiran dari perencanaan pertahanan yang ingin dirumuskannya dalam kebijakan pertahanan. Dalam laporannya, Dibb menolak konsep Forward Defence yang kerap menjadi strategi dasar kebijakan pertahanan Australia sebelumnya, Dibb menawarkan konsep Continental Defence. Konsep Continental Defence merupakan strategi kekuatan militer Australia harus dipersiapkan untuk menjaga dan mempertahankan benua Australia, atau benua Australia dan wilayah yang menjadi bagian dari kepentingan strategisnya, dan Australia tidak perlu melibatkan diri dalam berbagai perang di luar negeri.

Bob Hawke menolak saran tersebut dan cenderung menganut konsep "Forward Defence Within an Alliance", yang artinya pertahanan dengan konsep garis depan yang didalamnya masih terdapat aliansi. Setelah kepemimpinan Bob Hawke, Australia dipimpin oleh Perdana menteri yang berasal dari Partai Buruh yaitu Paul Keating. Paul Keating mengadopsi kebijakan pertahanan Defence White Paper 1987 era Bob Hawke. Kebijakan pertahanan Australia era Paul Keating dikenal dengan Defending Australia 1994. Bisa dikatakan tidak ada perubahan berarti dalam kebijakan pertahanan Australia era Paul Keating. Defending Australia 1994 berisi tentang rancangan pertahanan yang masih tetap 
terpaku pada aliansi serta memperluas hubungan dengan Indonesia, yang dianggap merupakan bagian penting di kawasan. Defending Australia 1994 era Paul Keating masih tetap terfokus pada aliansi dengan Amerika Serikat, sama halnya dengan kebijakan pertahanan era Bob Hawke. Hanya saja dalam "alur pergerakan" keamanan, Australia "menilik" Indonesia sebagai bagian awal dalam tahap pendekatan terhadap kawasan.

Pada tanggal 3 Desember 2007, pemimpin Partai Buruh Kevin Rudd, dilantik sebagai Perdana Menteri Australia yang baru menggantikan John Howard. Kenaikannya sebagai Perdana Menteri Australia diharapkan bisa membawa harapan baru secara domestik maupun internasional. Kemenangan Partai Buruh itu sekaligus merupakan jawaban atas penantian selama sebelas tahun sejak kalahnya PM Paul Keating pada Pemilu 1996. Sejak akhir 2007, pemerintahan Kevin Rudd tengah menyusun buku putih pertahanan Australia 2009 yang baru untuk menggantikan buku putih pertahanan 2000 yang diterbitkan di era PM John Howard. Di dalam Defence White Paper 2009 era Kevin Rudd, Australia menyatakan bahwa kebijakan pertahanan yang baru salah satunya adalah Self-Reliance yang intinya adalah kebijakan yang mengarah pada pertahanan kedaulatan dengan berdasarkan prinsip kemandirian. Berikut merupakan gambaran umum perbedaan yang diukur dari beberapa indikator, antara lain :

\begin{tabular}{|c|c|l|c|c|}
\hline No. & Indikator & $\begin{array}{c}\text { Defence white } \\
\text { paper 1987 }\end{array}$ & $\begin{array}{c}\text { Defending } \\
\text { Australia } \\
\mathbf{1 9 9 4}\end{array}$ & $\begin{array}{c}\text { Defence } \\
\text { White Paper } \\
\mathbf{2 0 0 9}\end{array}$ \\
\hline 1 & Konsep & $\begin{array}{l}\text { Forward } \\
\text { Defence }\end{array}$ & $\begin{array}{c}\text { Forward } \\
\text { defence }\end{array}$ & Self-Reliance \\
\hline 2 & Strategi & $\begin{array}{l}\text { Strategy in } \\
\text { depth }\end{array}$ & $\begin{array}{c}\text { Strategy in } \\
\text { depth }\end{array}$ & Self-Reliance \\
\hline 3 & $\begin{array}{c}\text { Sikap } \\
\text { terhadap }\end{array}$ & $\begin{array}{c}\text { Mendukung } \\
\text { aliansi }\end{array}$ & $\begin{array}{c}\text { Mendukung } \\
\text { aliansi }\end{array}$ & $\begin{array}{c}\text { Tidak } \\
\text { mendukung } \\
\text { (kemandirian) }\end{array}$ \\
\hline 4 & Ancaman & konvensional & konvensional & $\begin{array}{c}\text { non } \\
\text { konvensional }\end{array}$ \\
\hline 5 & Kepentingan & Ancaman & Ancaman & Isu keamanan \\
\hline
\end{tabular}




\begin{tabular}{|c|c|c|c|}
\hline strategis & $\begin{array}{c}\text { konvensional } \\
\text { dan Wilayah } \\
\text { teritori } \\
\text { australia }\end{array}$ & $\begin{array}{c}\text { konvensional } \\
\text { dan Wilayah } \\
\text { teritori } \\
\text { australia }\end{array}$ & $\begin{array}{c}\text { non } \\
\text { konvensional } \\
\text { dan kawasan } \\
\text { asia pasifik }\end{array}$ \\
\hline
\end{tabular}

Dilihat dari beberapa indikator yang telah dipaparkan di atas, seperti substansi, tujuan, strategi, ancaman, fondasi atau dasar keinginan, konsep, sikap terhadap aliansi, serta kepentingan strategis. Maka Defence White Paper 1987, 1994 dengan Defence White Paper 2009 jelas tampak berbeda.

Hubungan pertahanan Australia dan Amerika Serikat yang sudah terjalin lama dan berlangsung harmonis, memberikan dampak bagi kebijakan pertahanan Australia. Artinya bahwa Amerika Serikat selalu menjadi dasar pilihan dalam setiap kebijakan pertahanan Australia. "Ketergantungan" dengan Negara besar membawa Australia pada citra sebagai “pihak asing” di kawasan Asia.

Partai Buruh menjunjung tinggi prinsip kemandirian. Partai Buruh terus menunjukkan akar bekerja lewat upaya-upaya dalam perjuangan kelasnya. Partai Buruh berorientasi pada keinginan dasar untuk memperbaiki nasib pekerja, dengan menggunakan metode sosialis untuk mencapai tujuan-tujuannya. Dalam perkembangannya, dasar ideologi sosialis ini terus mengalami pergerseran. Pergeseran yang dimaksud lebih kepada upaya setiap anggota dalam memperjuangkan hak kaum buruh, sehingga tujuan ini kembali menjadi bahan perdebatan.

Partai Buruh yang terbagi dari fraksi kiri, tengah, dan kanan kerap mendapat kritik dari oposisi karena kebijakan yang diambil dinilai "menyimpang" dari ideologi Partai. Sebagai contoh, kaum sosialis kiri memperjuangkan kepentingan dan hak-hak kaum buruh dengan cenderung membuka kran bagi kaum industrialis untuk bekerja sama. Mereka berpendapat bahwa Negara dapat dikelola dengan bebas untuk keuntungan terbaik dari kelas pekerja. Prinsip yang kerap melekat dari sosialis kiri adalah tentang keuntungan yang didapat dari kerjasama tersebut. Artinya bahwa ada pertimbangan nilai untung rugi yang selalu menjadi dasar pertimbangan dari kaum kiri. Selama menguntungkan dan selama kepentingan kaum buruh terpenuhi, ini tidak akan menjadi soal karena yang 
menjadi hal utama adalah perjuangan pemenuhan hak-hak kaum buruh. Perusahaan-perusahaan yang terindikasi menindas buruh itulah yang menjadi target, namun perusahaan-perusahaan yang memberi untung dianggap sebagai bagian dalam perjuangan.

Ketika Australia dipimpin oleh Hawke-Keating, bagian yang menonjol adalah tentang kebijakan ekonomi yang selalu dinilai sedikit menyimpang dari unsur tradisionalis yang diperjuangkan oleh PM Buruh sebelumnya yaitu Whitlam. Hal ini terkait dengan Hawke-Keating yang berasal dari kaum kiri menerapkan kebijakan ekonomi yang dinilai cenderung membuka jalan bagi kaum industrialis serta cenderung mengandung unsur liberal.

Dalam perdebatan tentang pengembalian nilai-nilai perburuhan, akhirnya Emy dan Hughes meredefinisikan kembali makna perburuhan. Mereka berpendapat bahwa perburuhan bukanlah sesuatu hal yang selalu sama dengan sosialisme. Perburuhan adalah keberhasilan upaya pemimpin dalam memajukan kebijakan-kebijakan khusus yang bermanfaat bagi kelas buruh. Keberhasilan tersebut dilihat dari seberapa besar upaya setiap pemimpin dalam memperjuangkan jaminan sosial, pelayanan, jaminan kesehatan bagi kaum buruh. Perburuhan yang dimaksud menggabungkan elemen Workerism yang berpacu pada kesempatan memperoleh keuntungan yang sebesar-besarnya dari sistem industrialis atas nama kepentingan kaum buruh, bukan berusaha mengubah dasar dari ideologi tersebut. Prinsip seperti ini memungkinkan kebebasan dari setiap pemimpin dalam menerapkan kebijakan yang dianggap tepat bagi kaum buruh asalkan alur yang ada selalu berujung pada peningkatan kesejahteraan buruh.

Kebijakan pertahanan yang diambil oleh Hawke-Keating tentang pentingnya aliansi dengan AS merupakan cerminan dari kaum sosialis kiri. Mereka mempertimbangkan nilai untung rugi dalam aliansi tersebut. Ini terkait dengan pola politik dagang sapi yang selalu menjadi salah satu predikat dalam sistem kepartaian Australia. Tanpa bermaksud mengabaikan ideologi partai yang menganut prinsip kemandirian, sebenarnya aliansi merupakan bentuk baru industrialis di bidang pertahanan. Perlindungan AS dirasa memberi jaminan keamanan bagi Australia. Jaminan keamanan membantu Hawke-Keating untuk 
lebih fokus memperhatikan keadaan ekonomi Australia yang sedang dilanda krisis. Ketika pemulihan ekonomi tercapai, Australia dapat dengan mudah memperhatikan isu-isu lain yang nantinya bertujuan bagi perbaikan Australia yang lebih baik. Penulis melihat bahwa prinsip Hawke-Keating dalam kebijakan pertahanan mereka merupakan cara Hawke-Keating dalam memperjuangkan kepentingan Australia secara utuh.

Keutuhan yang dimaksud penulis merupakan bagian dari upaya HawkeKeating untuk merealisasikan makna perburuhan yang dipahami oleh kaum kiri. Pola pikir yang dianut Hawke-Keating sejajar dengan definisi perburuhan tersebut. Selama menguntungkan dan selama tujuan dari setiap keputusan yang diambil selalu bermuara pada kesejahteraan kaum buruh, maka hal tersebut dapat dimaklumi. Setelah Kepemimpinan Hawke-Keating, Partai Buruh menjadi pihak oposisi selama 11 tahun, karena pada tahun 1996, Australia dipimpin oleh John Howard dari pihak oposisi. Pada tahun 2007, Partai Buruh kembali "memainkan" peran dalam kursi kepemimpinan dengan terpilihnya Kevin Rudd sebagai PM Australia.

Kebijakan pertahanan Australia era Kevin Rudd dikenal dengan Defence White Paper 2009. Berbeda dengan Hawke-Keating yang mengedepankan pertahanan dengan perlindungan Negara AS, Kevin Rudd tidak ingin bergantung pada aliansi. Kevin Rudd memilih konsep kemandirian sebagai bagian dari kebijakan pertahanan Australia. Kevin Rudd kembali mencerminkan gaya kepemimpinan Partai Buruh yang selalu ingin terlihat independen. Prinsip kemandirian dikaitkan dengan sejarah dan ideologi Partai Buruh yang tidak pernah berkoalisi dengan partai lain baik ketika memerintah maupun menjadi pihak oposisi. Kevin Rudd yang berasal dari sosialis kanan merepresentasikan paham yang dianut kaumnya tentang kemandirian dan pengabaian hubungan dengan AS.

Makna perburuhan yang dipahami oleh kaum kanan jelas berbeda dengan kaum kiri. Kaum kanan kerap mengabaikan hubungan dengan AS, bahkan bisa dikatakan sangat anti dengan AS. Pemikiran yang dipertahankan kaum kanan adalah menjunjung tinggi prinsip ideologi Partai Buruh dalam bentuk 
kemandirian. Terlepas dari segala tujuan yang ingin dicapai demi tujuan kesejahteraan, kaum kanan tidak ingin "mencoreng" kemandirian yang selama ini terukir lewat sejarah tentang keberadaan Partai Buruh.

\section{Rumusan Masalah}

Dengan didasari pada uraian di atas, maka penulis memberikan batasan permasalahan pokok yang akan dibahas sebagai berikut :

Mengapa kebijakan pertahanan Australia dibawah Partai Buruh era HawkeKeating dan Kevin Rudd berbeda ?

\section{Kerangka Pemikiran}

Untuk menjelaskan tentang bagaimana arah kebijakan pertahanan Australia era Hawke-Keating dan Kevin Rudd serta perbedaan dari kebijakan pertahanan tersebut, maka dapat dijelaskan dengan beberapa pendekatan sebagai berikut :

\section{Teori kebijakan pertahanan menurut Douglas J. Murray dan Paul R. Viotti}

Menurut Douglas J. Murray dan Paul R. Viotti, sedikitnya ada empat hal yang mempengaruhi kebijakan pertahanan di setiap negara. Pertama, kondisi lingkungan internasional yang dapat dirasakan oleh setiap negara itu sendiri. Kedua, sasaran dari tujuan nasional, strategi dan doktrin kekuatan militer negaranya. Ketiga, proses dalam pembuatan pertahanan negara, dan keempat, berbagai isu yang sering terjadi. ${ }^{11}$ Jika di aplikasikan ke dalam kebijakan pertahanan Australia dari keempat faktor diatas, maka ada dua faktor mempengaruhi kebijakan pertahanan Australia, yaitu lingkungan internasional yang berkaitan dengan faktor eksternal, serta proses dalam pembuatan pertahanan Negara yang memuat elemen-elemen internal. Pertahanan merupakan salah satu elemen penting untuk mewujudkan tujuan nasional Australia. Sebagai bagian dari kepentingan nasional, maka kemampuan pertahanan yang baik merupakan hal

${ }^{11}$ Douglas J. Murray and Paul R. Viotti, The Defense Policies Of Nations: A Comparative Study, John Hopkins University Press, London, 1992, hal. 19. 
yang harus dimiliki oleh Australia. Salah satu upayanya adalah yaitu dengan membuat kebijakan pertahanan yang disesuaikan dengan kondisi internal maupun eksternal. Dalam Defence White Paper 1987, Defending Australia 1994, serta Defence White Paper 2009, Australia menyebutkan hal-hal yang akan dilakukan dalam upaya menjaga keamanan nasional. Keterkaitan faktor lingkungan internasional tidak dapat terlepas dari nama besar Amerika Serikat. Sejarah menggambarkan kedekatan hubungan antara Australia dan Amerika Serikat yang telah berjalan lama dan belangsung harmonis. Faktor internal dalam proses dalam pembuatan pertahanan Negara yang memuat tentang hal-hal yang terurai seperti kondisi domestik suatu Negara di bidang ekonomi. Disamping itu, faktor pemimpin turut berpengaruh dalam kebijakan tersebut. Hal ini berdasarkan pertimbangan rasional setiap pemimpin yang dapat membangun persepsi pemimpin dalam perumusan sebuah kebijakan pertahanan.

\section{Model Pembuatan Kebijakan menurut Graham T. Allison}

Pendekatan yang dapat digunakan yaitu pendekatan pembuatan kebijakan Menurut Graham T. Allison, dimana ada tiga model pembuatan keputusan politik luar negeri, yaitu Model Aktor Rasional, Model Proses Organisasi dan Model Politik Birokratis. Model yang akan digunakan sebagai kerangka pemikiran dalam skripsi ini adalah model Aktor Rasional.

Dalam model aktor rasional, pembuatan suatu kebijakan dipandang sebagai akibat dari tindakan-tindakan aktor rasional, terutama suatu pemerintah dengan sengaja untuk mencapai suatu tujuan. Pembuatan keputusan politik luar negeri digambarkan sebagai suatu proses intelektual. ${ }^{12}$ Perilaku pemerintah dianalogikan dengan perilaku individu yang bernalar dan terkoordinasi. Analisis model pembuatan keputusan ini adalah pilihan - pilihan yang di ambil oleh pemerintah sebagai alternatif-alternatif haluan kebijakan yang bisa diambil dengan perhitungan untung rugi atas masing-masing alternatif itu. Pertahanan merupakan cara untuk mengantisipasi dan mengawasi berbagai macam ancaman

\footnotetext{
12 Mohtar Mas'oed, Ilmu Hubungan Internasional: Disiplin dan Metodologi, LP3ES, Jakarta, 1990, hal. 275.
} 
yang datang baik dari dalam maupun dari luar. Dalam hal perumusan kebijakan pertahanan, terdapat berbagai pilihan-pilihan utama yang selalu menjadi fokus perhatian dari setiap pemimpin Australia. Pertama, apakah Australia harus terus bergantung pada perlindungan negara-negara besar seperti Amerika Serikat dan Inggris, yang dinilai dapat memberikan jaminan keamanan bagi Australia. Kedua yaitu apakah Australia perlu membangun sistem pertahanan yang mandiri sehingga diharapkan dapat lebih aktif dalam upaya serta inisiatif di forum internasional. Ketiga yaitu apakah Australia harus bertarung diluar negeri yang berkaitan dengan konsep Forward Defence atau Australia harus berperang didalam negeri yang sesuai dengan konsep Continental Defence.

Rasionalitas yang diterapkan pada Hawke-Keating melalui Defence White Paper 1987 dan Defending Australia 1994 merupakan respon atas situasi ekonomi yang dihadapi Australia saat itu. Sejak pemerintahan Malcolm Fraser di tahun 1977, angka pengangguran di Australia meningkat hampir dua kali lipat. Satu dari setiap 10 orang adalah penganggur, atau $10 \%$ dari jumlah tenaga kerja. Pertumbuhan ekonomi sama sekali tidak ada, sementara inflasi mencapai 11,3\% dalam kuartal terakhir 1982. Ekonomi Australia selama beberapa tahun terakhir tidak hanya menderita akibat resesi dunia. Cuaca dan bencana alam juga menimbulkan kerusakan parah pada dunia pertaniannya. ${ }^{13}$

Pada awal kepemimpinannya, Bob Hawke mempertimbangkan situasi tersebut sebagai fokus yang harus diperhatikannya. Melihat situasi ekonomi yang seperti itu Bob Hawke memilih untuk membangun sistem ekonomi yang kuat dengan sedikit "mengabaikan" masalah keamanan. Pertahanan tetap menjadi perhatian namun dengan cara menyandarkan diri kepada AS. Dalam penyusunan Defence White paper 1987, Bob Hawke memilih konsep Forward Defence atau Pertahanan dengan menempatkan kekuatan jauh di Garis Depan. Dengan mempertimbangkan berbagai situasi saat itu dimana dalam perencanaan telah dijelaskan bahwa Australia masih tetap menyandarkan diri pada AS dalam hal

\footnotetext{
13 “Buruh Menang Lalu?", dalam http://majalah.tempointeraktif.com/id/arsip/1983/03/12/LN/mbm.19830312.LN45541.id.html, diakses pada 25 Januari 2012.
} 
komunikasi dan bidang intelejen. Pertimbangannya Australia mendapat keuntungan apabila beraliansi dengan AS.

Dasar pemikiran saat itu adalah lebih baik berperang melawan musuh di bumi orang lain dan mencegah musuh untuk berada di kawasan Australia, karena Australia pada saat itu tidak memiliki kemampuan yang besar untuk mengusir musuh apabila terjadi perang. Itulah sebabnya Australia mengambil posisi di kawasan bersama - sama dengan aliansi AS sebagai pendukung. Pasca Tahun 1990, Australia kembali mengalami masalah ekonomi yang ditandai dengan hutang luar negeri yang semakin membengkak dan defisit neraca berjalan, serta adanya ketimpangan antara pendapatan serta pengeluaran anggaran.

Kondisi ini semakin memperkeruh pertahanan Australia. Pada Pemilu 1990, dalam kampanyenya Partai Buruh menjanjikan penyesuaian ekonomi. Keating yang menggantikan Hawke pada 1991, dihadapkan pada permasalahan yang lebih buruk dibanding awal pemerintahan Hawke. Australia dihadapkan pada permasalahan peningkatan penggangguran yang mencapai $11 \%$ serta resesi ekonomi Australia yang cukup lama dibanding resesi tahun 1983-1984. ${ }^{14}$ Melihat keadaan ini, sesuai dengan janji kampanye Partai Buruh, akhirnya diawal kepemimpinannya Keating lebih mengarahkan perhatian pada kondisi ekonomi Australia. Alur pemikiran yang hampir sama dengan Bob Hawke kembali ditunjukkan pada pembuatan kebijakan pertahanan Australia yang dituang dalam Defending Australia 1994. Defending Australia 1994 masih tetap sama Defence White Paper 1987 era Bob Hawke.

Pada sisi lain, rasionalitas yang diterapkan oleh Kevin Rudd melalui Defence White Paper 2009 merupakan rancangan berkala Australia terhadap respon dari berbagai perubahan di lingkungan geo-strategis, seperti melemahnya penampilan Amerika Serikat sebagai negara yang memiliki peran tunggal dalam lingkungan internasional yang ditandai oleh peristiwa krisis ekonomi AS tahun 2008. Sementara itu, dilihat dari kondisi ekonomi Australia di era Kevin Rudd, Australia memiliki ekonomi yang kuat ditandai dengan terhindarnya Australia dari

\footnotetext{
${ }^{14}$ Muharjono, Dinamika Kebijakan Pemerintahan Partai Buruh Australia era Hawke-Keating, Tesis Pascasarjana UGM, Yogyakarta, Hal.23.
} 
dampak krisis keuangan global. Sedangkan kebangkitan militer Cina ternyata diperkuat aspek ekonominya guna menyokong dimensi militer dalam konsep keamanan nasionalnya. Cina mengumumkan peningkatan dana pembelanjaan militer sebesar 17,6\%. Total anggaran belanja militer Cina pada tahun 2008 mencapai sekitar 418 juta yuan. Pemerintah militer Cina menyatakan bahwa peningkatan anggaran militer tersebut ditujukan untuk memperkuat dan memperbaiki kelemahan pertahanan Cina. ${ }^{15}$

Dihadapkan pada realitas sedemikian rupa ini, pemerintahan Kevin Rudd menghadapi pilihan dilematis. Pertimbangan yang diambil tak lepas dari pilihan apakah tetap bergantung pada perlindungan negara seperti AS ataukah membangun suatu sistem pertahanan yang mandiri. Dalam proses pembuatan kebijakan tersebut Kevin Rudd merasa Australia dengan kondisi ekonomi yang kuat serta kenyataan melemahnya performance AS, akhirnya memilih untuk dapat membangun pertahanan yang mandiri. Australia menerapkan Defence Self Reliance serta meningkatkan strategi pertahanan yang lebih kokoh. Salah satu komponen utama dari pertahanan nasional Australia adalah ADF. Pertimbangan saat itu yaitu untuk dapat mencapai pertahanan yang mandiri dengan ekonomi yang kuat, pemerintah Australia harus meningkatkan kemampuan ADF baik secara teknis maupun keahlian mereka sehingga dapat bekerja secara baik dalam menjaga keamanan nasional Australia dan turut berpartisipasi dalam menjaga keamanan dunia.

\section{Hipotesis}

Berdasarkan kerangka pemikiran di atas, alasan terjadinya perbedaan antara kebijakan pertahanan Partai Buruh Australia era Hawke-Keating dan Kevin Rudd adalah karena adanya perbedaan Fondasi dari Hawke-Keating dan Kevin Rudd, meliputi persepsi dan situasi domestik Australia di bidang ekonomi serta perubahan performance Amerika Serikat di bidang ekonomi dan militer.

\footnotetext{
15“Kemampuan Militer Cina Cemaskan AS", dalam http://www.pikiranrakyat.com/index.php?mib=beritadetail\&id=15748, diakses pada 25 Januari 2012.
} 


\section{KESIMPULAN}

Beberapa faktor yang mendukung adanya perbedaan kebijakan pertahanan Australia era Hawke-Keating dan Kevin Rudd antara lain, karena adanya perbedaan Fondasi dari Hawke-Keating dan Kevin Rudd meliputi persepsi dan situasi domestik Australia di bidang ekonomi serta adanya perubahan peran Amerika serikat yang ditinjau dari bidang ekonomi dan militer. Keterkaitan faktor eksternal yang hanya mengakar pada performance Amerika Serikat sebenarnya dipilih sebagai bagian dari faktor sejarah Australia yang selalu melandaskan pertahanan pada pilihan-pilihan pada sandaran Negara-negara besar.

Hawke-Keating berkeyakinan bahwa untuk dapat bertahan, Australia tidak dapat melakukannya sendiri, maka perlindungan Amerika Serikat sangat penting, sehingga posisi Amerika Serikat di depan dapat melindungi Australia. Dengan berlakunya Forward Defence, maka Australia lebih mudah dalam menghadapi ancaman-ancaman potensial yang berpengaruh bagi kepentingan nasional dan keamanannya seperti komunisme, karena kekuatan-kekuatan besar yang menjadi sekutunya menempatkan diri sebagai pelindung Australia.

Kevin Rudd melihat perubahan strategis lingkungan geopolitik Australia sebagai bagian yang penting yang tidak dapat diabaikan. Kondisi ekonomi Australia di era Kevin Rudd yang kuat dijadikan sebagai peluang dalam keyakinan mampu berdiri sendiri memunculkan ketegasan tentang tidak perlunya menggantungkan keamanan terhadap negara lain. Hal ini diperkuat dengan fakta melemahnya performance Amerika Serikat sebagai negara yang memiliki peran tunggal dalam lingkungan internasional selama beberapa dekade. Faktor lain yaitu kondisi ekonomi AS tahun 2008, yang dilanda krisis.

Bagaimana mungkin Australia harus menyandarkan diri pada aliansi keamanan dengan Amerika Serikat sedangkan dalam perkembangan di era Kevin Rudd, Amerika Serikat tengah diperhadapkan dengan berbagai macam permasalahan. Keyakinan itu semakin diperparah dengan melihat Amerika Serikat yang dulunya sangat "disegani" karena kekuatan militer, ekonomi, teknologi dan peran dalam berbagai permasalahan dunia, kini mulai bergeser dan merosot akibat munculnya kekuatan baru seperti Cina yang tidak dapat diabaikan. Cina 
memberikan tantangan yang signifikan secara ekonomi, militer dan politik tidak hanya bagi Asia Tenggara, tetapi secara tidak langsung hal ini merupakan ancaman bagi eksistensi Australia.

\section{DAFTAR PUSTAKA}

\section{Buku:}

Chauvel, Richard H. Budaya dan Politik Australia, terj.oleh Harlinah, Sujinah,Yayasan Obor Indonesia, Jakarta, 1992.

Firth, Stewart. Australian in International Politics: Introduction to Australian Foreign Policy, Allen\&Unwin, New South Wales, 1999.

Hamid, Zulkifli. Sistem Politik Australia, PT. Remaja Rosdakarya, Bandung, 1999.

Mas'oed, Mohtar. Ilmu Hubungan Internasional: Disiplin dan Metodologi, LP3ES, Jakarta, 1990.

Mas'oed, Mohtar. Studi Hubungan Internasional : Tingkat Analisis dan Teorisasi,

Pusat Antar Universitas-Studi Sosial UGM, Yogyakarta, 1989.

Murray J. Douglas and Paul R. Viotti, The Defense Policies Of Nations: A Comparative Study, John Hopkins University Press, London, 1992.

Sunardi, Politik Luar Negeri Australia dibawah Partai Buruh, Grafindo Utama, Jakarta, 1985.

Muharjono, Dinamika Kebijakan Pemerintahan Partai Buruh Australia era Hawke-Keating, Tesis Pascasarjana UGM, Yogyakarta, 2000.

Tedy Sutari, Lingkungan Eksternal Persepsi Tentang Ancaman dan Dampaknya Terhadap Modernisasi Militer Di Cina (2000-2004), Skripsi FISIP UPN "Veteran" Yogyakarta, Yogyakarta, 2006. 


\section{Internet (Website):}

"2009, Ekonomi Australia Tumbuh 2,7\%", dalam http://economy.okezone.com/read/2010/03/04/213/308928/2009-ekonomiaustralia-tumbuh-2-7, diakses pada 2 Maret 2012.

"A New White Paper", dalam http://www.defence.gov.au/whitepaper/discusspaper.html, diakses pada 9 juli 2011.

Achievability of Self-Reliance Within an Alliance Framework Defence Policy", dalam http://www.defence.gov.au/jetwc/docs/publications\%202010/PublcnsGeddes20 03_300310_AchievabilityofSelfReliance.pdf, diakses pada 22 Januari 2012.

"Aliansi Australia-AS: Telah Terjalin Selama 60 Tahun Namun Kian Penting karena Asia Bangkit", dalam http://www.antaranews.com/berita/272282/aliansiaustralia-as-telah-terjalin-selama-60-tahun-namun-kian-penting-karena-asiabangkit, diakses pada 8 Maret 2012.

“Amerika Serikat, Negara Masa Lalu? ", dalam http://www.inilahjabar.com/read/detail/957762/amerika-serikat-negara-masalalu, diaksespada 10 Februari 2012.

"Asia-Pacific Economic Cooperation (APEC)", dalam http://www.dfat.gov.au/apec/index.html, diakses pada 10 Maret 2012.

"Australia", dalam http://www.kemlu.go.id/canberra/Pages/CountryProfile.aspx?l=id, diakses pada 21 Januari 2012.

Australia's Defence Doctrine", dalam http://www.globalsecurity.org/military/world/australia/doctrine.htm, diakses pada 21 Januari 2012.

Australian Defence Policies: Alliance or Independence?", dalam http://www.international-relations.com/wbip/wbnlec5.htm, diakses pada 24 Februari 2012.

"Australia's New Defence White Paper Ministerial Address To ASPI", dalam http://www.minister.defence.gov.au/Fitzgibbontpl.cfm?Currentld=9106, diakses pada 29 September 2011. 
"Australia's Defence Policy", dalam http://www.defence.gov.au/whitepaper/docs/defence_white_paper_2009.pdf, diakses pada 30 Maret 2012.

"Austalia's Strategic Interest", dalam http://isbirligi.ssm.gov.tr/Lists/Raporlar/Attachments/30/Australia\%20Defence_ White_Paper_2009.pdf, diakses pada 20 Januari 2012.

“Australia's Trade Performance 1988-89 to 2008-09", dalam http://www.dfat.gov.au/publications/stats-pubs/australias-trade-performance1988-89-to-2008-09.pdf, diakses pada 2 Februari 2012.

"Australia-US Alliance“, dalam http://www.dfat.gov.au/geo/us/australia_us_alliance.html, diakses pada 9 Maret 2012.

"Australia-United States Free Trade Agreement (AUSFTA)", dalam http://www.austrade.gov.au/ausfta/default.aspx, diakses pada 8 Maret 2012.

"Biography of Gough Whitlam", dalam http://www.whitlamdismissal.com/whitlam/biography.shtm, diakses pada 8 Maret 2012.

"Biography of John Curtin" dalam http://john.curtin.edu.au/resources/biography/details.html, diakses pada 8 Maret 2012

"Bob Hawke" dalam http://www.australiaonnet.com/about-australia/famousaustralians/bob-hawke.html, diakses pada 2 Desember 2011.

"Budget Paper No. 2:Budget Measures 2009-10" dalamhttp://www.budget.gov.au/2009-10/content/bp2/html/index.htm, diakses pada 29 September 2011.

"Buruh Menang Lalu?", dalam http://majalah.tempointeraktif.com/id/arsip/1983/03/12/LN/mbm.19830312.LN 45541.id.html, diaksespada 25 Januari 2012.

“Chifley, Joseph Benedict (Ben) (1885-1951)", dalam http://adb.anu.edu.au/biography/chifley-joseph-benedict-ben-9738, diakses pada 8 Maret 2012.

"Daftar Jumlah Pesawat Tempur Fighter Tiap Negara", dalam http://www.duniamiliter.com/2011/08/daftar-jumlah-pesawat-tempurfighter.html, diakses pada 8 Maret 2012. 
"Daftar Kapal Perang Nuklir di Dunia", dalam http://www.duniamiliter.com/2011/08/daftar-jumlah-kapal-selam-nuklirdi.html, diakses pada 8 Maret 2012.

"Daftar Negara Pengguna Kapal Induk", dalam http://www.duniamiliter.com/2011/08/daftar-negara-pengguna-kapalinduk.html, diakses pada 8 Maret 2012.

"Defence Focuses on China" dalam http://www.couriermail.com.au, diakses pada 12 Januari 2012.

"Defence White Papers: An Alternative View", dalam http://www.rusinsw.org.au/Papers/20080930.pdf, diakses pada 29 September 2011.

"Defending Australia In The Asia Pasific Century: Force 2030," dalam http://www.defence.gov.au/whitepaper/docs/defence_white_paper_2009.pdf, diakses pada 17 Mei 2011.

"Diplomasi AS Terhadap Negara-negara Eropa abad ke-19", dalam http://file.upi.edu/direktori/fpips/jur._pend._sejarah/196904301998021moch_e ryk_kamsori/sej.amerika/bahan_ajar/bab_ix.bangsa_amerika.pdf, diakses pada 10 Februari 2012.

"Domestic Politics to 1975", dalam http://www.britannica.com/EBchecked/topic/43654/Australia/42431/Australiafrom-1945-to-c-1983\#ref475450, diakses pada 8 Maret 2012.

"Economic Crisis", dalam :http://doyle.house.gov/legislation/economiccrisis.shtml, diakses pada 2 Februari 2012.

"Ekonomi AS Angka Pengangguran Naik, Tapi PHK Turun", dalam http://www.voanews.com/indonesian/news/a-32-2009-06-06-voa585421867.html, diakses pada 2 Februari 2012.

"Geografi Australia", dalam http://www.studyinaustralia.gov.au/id/Living-in Australia/Geography/Australian-Geography, diakses pada 20 januari 2012.

"Hegemonic Instability and East Asia: Contradictions, Crises and US power", dalamhttp://uwa.academia.edu/MarkBeeson/Papers/537032/Hegemonic_instab ility_and_East_Asia_Contradictions_crises_and_US_power, diakses pada 8 Maret 2012. 
"History, Politics, Economics and Cultural Interactions", dalam http://australiaushistory.com/,diakses pada 8 Maret 2012.

"How Prepared Does the ADF Need to $\mathrm{Be}^{\text {" dalam }}$ http://www.defence.gov.au/whitepaper/docs/defence_white_paper_2009.pdf, diakses pada 8 Mei 2011.

"Jumlah Tentara Aktif dan Cadangan di SeluruhDunia", dalam http://www.duniamiliter.com/2011/08/jumlah-tentara-aktif-dan-cadangandi.html, daikses pada 8 Maret 2012.

"Kebijakan Pertahanan Australia dan Respon Negara-Negara Asia Timur dan Selandia Baru", dalam http://www.elib.pdii.lipi.go.id/katalog/index.php/searchkatalog/.../7575.pdf, diakses pada 20 Januari 2012.

"Kemampuan Militer Cina Cemaskan AS", dalam http://www.pikiranrakyat.com/index.php?mib=beritadetail\&id=15748, diakses pada 25 Januari 2012

"National Economic Update", dalam http://dallasfed.org/research/updateus/2008/0808.cfm, diakses pada 2 Februari 2012.

"Partai", dalam http://www.indonesia.embassy.gov.au/jaktindonesian/sistem_pemerintahan.ht $\mathrm{ml}$, diakses pada 25 Januari 2012.

"Paul Dibb", dalam http://www.defencesa.com/defence-sa/defence-sa-advisoryboard/professor-paul-dibb-am-phd, diakses pada 20 Januari 2012.

"Paul Keating", dalam http://www.answers.com/topic/paul-keating V \# ixzz1nBdEv7we, diakses pada 26 Februari 2012.

"Perkembangan dalam Hubungan Internasional Australia", dalam http://www.dfat.gov.au/aii/publications/bab11/untuk.html, diakses pada 8 Maret 2012.

"Performance", dalam http://www.kamus.net/result.php?w=enusa\&q=performance\&submit=Search\&e=0, diakses pada 5 Februari 2012.

"Perimbangan Kekuatan Ekonomi dan Militer RRC-AS", dalahttp://economy.okezone.com/read/2010/02/12/279/302924/279/perimban gan-kekuatan-ekonomi-dan-militer-rrc-as, diakses pada 10 Februari 2012. 
"PM Howard Perintahkan Tambahan Tentara kelrak", dalam http://indonesiaindonesia.com/f/12331-pm-howard-perintahkan-tambahantentara-irak/, diakses pada 10 Maret 2012.

"Politic Conditions", dalam http://www.state.gov/r/pa/ei/bgn/2698.htm, diakses pada 20 Januari 2012.

"Sejarah Abad ke 20", dalam http://www.studyinaustralia.gov.au/id/Living-inAustralia/History/, diakses pada 1 Desember 2011.

"Sejarah Australia", dalam http://www.studyinaustralia.gov.au/id/Living-in Australia/History/Australian-History, diakses pada 20 Januari 2012.

"Sistem Ekonomi", dalam

http://www.kemlu.go.id/canberra/Pages/CountryProfile.aspx?l=id, Diakses pada 3 Februari 2012.

"Sistem Pemerintahan Australia", dalam http://www.indonesia.embassy.gov.au/jaktindonesian/sistem_pemerintahan.ht $\mathrm{ml}$, diakses pada 19 Januari 2012.

"Sekenario Aussie Terhadap Data Pasar Tenaga Kerja Australia", dalam http://www.seputarforex.com/analisa/fundamental/forex.php?id=71061\&topic=se kenario_aussie_terhadap_data_pasar_tenaga_kerja_australia, diakses pada 2 Maret 2012.

"The 2003 Defence Statement: The Failure to Marry Politics and Policy", dalam http://www.australianreview.net/digest/2003/04/woolner.html, diaksespada 1 Februari 2012.

"The ALP Left and Australian Defence Policy", dalam http://sciencesecurity.wordpress.com/2008/05/05/thalp-left-and-australiandefence-policy/, diakses pada 21 Januari 2012.

"The Defence of Australia 1987", dalam http:// www.securitychallenges.org.au/, diakses pada 10 November 2011.

"The Defence Of Australia and the limits of Land Power ", dalamhttp://www.securitychallenges.org.au/ArticlePDFs/vol3no4Stephens.pdf, diaksespada 29 Desember 2011.

"The Defence White Paper" dalam http://www.defence.gov.au/publications/White\%20Paper\%20Booklet.pdf, diakses pada 20 Januari 2012. 